\title{
Household Cooking Fuel Type and Child Anaemia in Sub-saharan Africa: Insights From Demographic and Health Surveys
}

Iddrisu Amadu ( $\square$ iddrisu.amadu@stu.ucc.edu.gh )

University of Cape Coast School of Biological Sciences https://orcid.org/0000-0003-4839-1197

Abdul-Aziz Seidu

University of Cape Coast, Department of Population and Health

Abdul-Rahaman Afitiri

University of Cape Coast, Department of Environmental Science

Bright Opoku Ahinkorah

University of Technology, Faculty of Health, The Australian Centre for Public and Population Health Research

\section{Research}

Keywords: Anaemia, Under-five Children, Sub-Saharan Africa, DHS, Public Health

Posted Date: August 2nd, 2020

DOl: https://doi.org/10.21203/rs.3.rs-49470/v1

License: (c) (i) This work is licensed under a Creative Commons Attribution 4.0 International License. Read Full License 


\section{Abstract \\ Background}

Childhood anaemia is one of the major public health concerns in low and middle-income countries, contributing substantially to childhood mortality and morbidity. This study, therefore, sought to investigate the association between household cooking fuel type, and the joint impact of household cooking fuel type and urbanicity on anaemia among children under the age of 5 in sub-Saharan Africa.

\section{Methods}

We analysed cross-sectional data of 95,056 children under the age of 5 from 29 sub-Saharan African countries. Bivariate and multivariate analyses were performed using chi-square test of independence and negative log-log regression respectively at $p<0.05$. Results were presented as Adjusted Odds Ratios for the negative log-log regression analysis.

\section{Results}

The percentage of children who had anaemia was $57 \%$. Children from rural households that depend on unclean cooking fuels were more likely to be anaemic $[A O R=1.042 ; 95 \% \mathrm{Cl}=1.010-1.074]$ compared to children from urban households using unclean cooking fuel. We also found that children in female headed households $[A O R=1.047 ; \mathrm{Cl}=1.019-1.076]$, children in large households [AOR $=1.066 ; \mathrm{Cl}=1.021-1.113]$; those in households with improved source of drinking water $[\mathrm{AOR}=1.035 ; \mathrm{Cl}=1.006-1.065]$ had higher odds of suffering from anaemia. However, children with normal weight $[\mathrm{AOR}=0.946 ; \mathrm{Cl}=0.916-$ 0.976 ], children aged 4 [AOR $=0.900 ; \mathrm{Cl}=0.868-0.934]$, children whose mothers are aged $45-49[\mathrm{AOR}=0.866 ; \mathrm{Cl}=0.778-0.963]$ and those aged $30-34$ [AOR $=0.868 ; \mathrm{Cl}=0.815-0.925]$, children whose mothers had tertiary level of education $[\mathrm{AOR}=0.865 ; \mathrm{Cl}=0.809-0.925]$, children in rich households [AOR $=0.935 ; \mathrm{Cl}$ $=0.904-0.968]$ and those in households with improved type of toilet facility $[\mathrm{AOR}=0.955 ; \mathrm{Cl}=0.929-0.981]$ had lower odds of being anaemic .

\section{Conclusion}

Our study established an association between the joint effect of type of household cooking fuel and urbanicity and anaemia among children under the age of 5 in SSA. Childs' birthweight, current age, maternal age, sex of household head, age of household head, maternal education, wealth status, size of household, type of source of drinking water and country of residence are associated with childhood anaemia. It is therefore critical to promote the usage of clean cooking fuels among households and women in rural areas. This could be done by governments in various countries subsidising the cost of liquefied petroleum gases and cylinders. Stakeholders that seek to improve maternal and child health should also take these associated factors into consideration.

\section{Background}

In low and middle-income countries, anaemia remains a major public health problem which causes childhood mortality and morbidity (Ntenda et al., 2018). Anaemia is a condition in which the heamoglobin level is lower than the body's required amount for physiological activities (Roberts, Mattews \& Sartorius, 2020). According to WHO (2011), about 273.2 million children suffer from anaemia globally with a general prevalence of $42.6 \%$. However, its effects are disproportionate across regions, with sub-Saharan Africa (SSA) being one of the most affected with a startling prevalence rate of $62.3 \%$ (Nambiema, Robert \& Smith, 2019).

Anaemia is major contributor to some of the serious adverse health conditions in children and affects their cognitive, behavioral and physical development (Gener et al., 2013; Soliman, De Sanctis \& Kalra, 2014; WHO, 2011; Wirth et al., 2016). The notable causes of anaemia in children are multifactorial and include deficiency of iron, and other micronutrients such as folate, vitamin B12 and vitamin A; malaria, HIV and chronic disease such as sickle cell disease (WHO, 2014).

Apart from these causes, a major environmental cause of anaemia is indoor air pollution as a result of biomass fuel use in cooking in households (Mishra, \& Retherford, 2007). Household biomass fuel is a global air pollution issue that harms human health, the climate and the environment. About three billion people use biomass fuels such as plant residues, animal dung, wood and charcoal for daily domestic use (Van Gemert et al., 2016). Inefficient combustion of these fuels could release harmful gases such as sulphur dioxide $\left(\mathrm{SO}_{2}\right)$, carbon monoxide $(\mathrm{CO})$ and nitrogen dioxide $\left(\mathrm{NO}_{2}\right)$, and Particulate Matter $(\mathrm{PM})(\mathrm{Machisa}$, Wichmann \& Nyasulu, 2013; Wolley et al., 2020). According to WHO (2006), households that use biomass fuels are often exposed to peak indoor particulate matter $\left(\mathrm{PM}_{10}\right)$ levels greater than the air quality guidelines. The mechanism by which biomass fuels use could contribute to childhood anaemia are unknown. However, studies have shown that biomass fuel expels high carbon monoxide levels which bind with hemoglobin, form carbonxyhaemoglobin and reduce the level of haemoglobin in the blood, which leads to anaemia. For instance, studies in India (Mishra \& Retherford, 2007) and Swaziland (Machisa, Wichmann \& Nyasulu, 2013) found the prevalence of anaemia to be significantly high among children in households that rely on biomass fuels for cooking.

Apart from anaemia, evidence of other adverse health outcomes spanning respiratory illnesses, cancer and eye problems from indoor-air pollution due to inefficient burning of biomass fuels for cooking in poorly ventilated settings exist (Amegah, Boachie, Näyhä \& Jaakkola, 2019; Page, Patel \& Hibberd, 2015; Kyu, Georgiades \& Boyle, 2010). A majority of the burden is suffered by women who by custom are responsible for cooking and other household chores, and their children, especially, those below the age of 5 (Desai, Mehta \& Smith, 2004; WHO, 2006). The prevalence of the burden is relatively low in urban areas where clean fuels like liquid petroleum gas or natural gas and electricity are typically used. However, most rural residents mainly depend on biomass fuels (Begum et al., 2009). These fuels include among others wood, animal dung, twigs and dry leaves, and crop residues such as straw and rice husks 
(Chakraborty, Mondal, \& Datta, 2014). The high burden of adverse health outcomes among rural residents is that most of them often depend on unclean cooking fuels (Pinto, 2016; Page, Patel, \& Hibberd, 2015; Baranwal, Baranwal, \& Roy, 2014).

The associations between household biomass fuel use in cooking and important health variables of women and children such as adverse pregnancy outcomes (low birth weight, stillbirth) (Amega, Quansah \& Jaakkola, 2014; Epstein et al., 2013); women health (BMI, anaemia) (Ali, Khan \& Feroz, 2020; Amegah, Boachie, Näyhä \& Jaakkola, 2019); and the health of children under 5 years of age (child weight, child anaemia) (Kyu, Georgiades \& Boyle, 2010; Epstein et al., 2013) have been explored. Few studies have explored the association between household biomass fuel use, a notable source of indoor air pollution in LMICs with child anaemia in SSA. Further, critical to our understanding but absent in such sub-regional analysis by studies is the joint impact of household biomass fuel use and urbanicity on child anaemia in SSA. This study therefore seeks to investigate the joint effect of household biomass fuel use for cooking and urbanicity on anaemia among children under the age of 5 in SSA.

\section{Materials And Methods}

\section{Data Source}

Nationally representative data from the Demographic and Health Surveys (DHS) Program for SSA countries from 2010 to 2018 were acquired for analysis in this study. The DHS program provides a large secondary data gathered from surveys using probability sampling methods, following standard protocols that are internationally accepted. Different sets of questionnaires designed and pre-tested to ensure reliability and amenability for comparison of data gathered on various spatial and temporal scales are used in the survey. Some questionnaires the program uses include the "Children's questionnaire" "Mother's questionnaire", "Men's questionnaire" and "Household questionnaire". These questionnaires cover a broad range of variables cutting across demographics and anthropometrics, water and sanitation, health, wealth, nutrition among others. The program recruits and trains field officers to collect accurate data and measurement of weight, height, anaemia using recommended guidelines and instruments. Data on other important variables such as household cooking fuel, urbanicity, wealth, water and sanitation are taken at the household level.

\section{Study Countries}

A sample of 95,056 was drawn from 29 countries in SSA (show in Fig. 1). For a country to be selected, it must meet the following criteria; should be found in SSA based on the United Nations regional groupings; it must have a DHS dataset with standardized questions and observations on anaemia level of children under five years as well as household cooking fuel type, urbanicity, source of drinking water and type of toilet facility. Where multiple datasets exist for a country, the most recent dataset is used. Detailed information on countries, together with years of survey are shown in Table 1.

Table 1

Selected countries and available dataset

\begin{tabular}{|llll|}
\hline Country & Available dataset & Country & Available dataset \\
\hline Angola & 2016 & Malawi & 2016 \\
\hline Benin & 2018 & Mali & 2018 \\
\hline Burkina Faso & 2010 & Mozambique & 2015 \\
\hline Burundi & 2017 & Namibia & 2013 \\
\hline Cameroon & 2019 & Niger & 2012 \\
\hline Congo & 2012 & Nigeria & 2018 \\
\hline Cote D'Ivoire & 2012 & Rwanda & 2015 \\
\hline DR Congo & 2014 & Sierra Leone & 2013 \\
\hline Ethiopia & 2016 & Senegal & 2017 \\
\hline Gabon & 2012 & Tanzania & 2016 \\
\hline Gambia & 2013 & Togo & 2014 \\
\hline Ghana & 2014 & Uganda & 2016 \\
\hline Guinea & 2018 & Zambia & 2019 \\
\hline Lesotho & 2014 & Zimbabwe & 2015 \\
\hline South Africa & 2016 & & \\
\hline
\end{tabular}

\section{Definition Of Important Variables}

The dataset provided information on household cooking fuel type, source of drinking water and toilet facility type at the household level. The observations for household cooking fuel were classified into "Clean" and "Unclean" (polluting fuels) following the criterion some studies (Naz, Page and Agho, 2017; Sreeramareddy, Shidhaye \& Sathiakumar, 2011) used (see Table 2). The weight of child at birth named as "Birth weight" was categorized as "Underweight" (< 
$2.5 \mathrm{~kg}$ ) and "Normal" ( $\geq 2.5 \mathrm{~kg}$ ) (see, Yaya et al., 2019). Also, the observations for household source of drinking water and type of toilet facility were classified into "improved" and "unimproved" using the revised definitions by the WHO/UNICEF Joint Monitoring Programme (JMP) report (World Health Organization \& UNICEF, 2017). Table 2 summarises the descriptions of improved and unimproved sources of water and toilet facilities. Armah et al. (2018) further explicates the categorisation of these critical basic services.

Table 2

Classification of source of drinking water and toilet facilities under WHO/UNICEF Joint Monitoring Programme and cooking fuel.

\begin{tabular}{|lll|}
\hline Service & Improved/Clean & Unimproved/Unclean \\
\hline $\begin{array}{l}\text { Drinking } \\
\text { water } \\
\text { sources }\end{array}$ & $\begin{array}{l}\text { Piped water, boreholes or tube wells, protected dug wells, protected springs, } \\
\text { rainwater, and packaged or delivered water. }\end{array}$ & $\begin{array}{l}\text { Unprotected dug well, unprotected spring, river, dam, } \\
\text { lake, pond, stream, canal and irrigation canal }\end{array}$ \\
\hline $\begin{array}{l}\text { Type of } \\
\text { toilet } \\
\text { facilities }\end{array}$ & $\begin{array}{l}\text { Flush/pour flush to piped sewer systems, septic tanks or pit latrines; ventilated } \\
\text { improved pit latrines, composting toilets or pit latrines with slabs. }\end{array}$ & $\begin{array}{l}\text { Pit latrines without a slab or platform, hanging latrines } \\
\text { or bucket latrines and open defecation. }\end{array}$ \\
\hline $\begin{array}{l}\text { Cooking } \\
\text { fuel type }\end{array}$ & Electricity, liquid petroleum gas (LPG), natural gas and biogas & $\begin{array}{l}\text { Kerosene, coal/lignite, charcoal, wood, } \\
\text { straw/shrubs/grass and animal dung }\end{array}$ \\
\hline
\end{tabular}

\section{Measures}

\section{Outcome variable}

Anaemia status of children is the outcome variable considered in this study. According to DHS, the anaemia status of living children within the age bracket 0 4 years before the survey night was taken. It has its responses classified into four (4) categories according to the WHO recommendation as: (i) "Not anaemic" for children with hemoglobin count(g/dl) measuring above $11 \mathrm{~g} / \mathrm{dl}$; (ii) "Mild anaemia" for hemoglobin count of 10-10.9 g/dl; (iii) "Moderate anaemia" for hemoglobin count between 7.0-9.9 g/dl; and (iv) "Severe anaemia" for hemoglobin count less than $7.0 \mathrm{~g} / \mathrm{dl}$. Children with no observations for anaemia count (not tested), and those whose mothers were not listed in the household questionnaire were excluded. Observations under mild, moderate and severe were combined and recoded as "Anaemic (Yes)" and observations under not anaemic was recoded as "Not anaemic (No)". The Anaemia status of children was represented as a dichotomous variable with "0" representing "No" and 1 representing "Yes"

\section{Main Predictor Variable}

The predictor chosen for this study is a composite variable formed from the interactive effect of household cooking fuel type and urbanicity. The selection of the predictor variable was based on parsimony, literature review, theoretical relevance as well as practical significance. Household cooking fuel type and Urbanicity both had two categories, since the former was classified into "Clean" and "Unclean" and the latter measured as "Rural" and "Urban" per the Demographic Health Survey (DHS). This therefore gave a four mutually exclusive groups: Unclean urban (households relying on "unclean" cooking fuel and found in urban areas); Unclean rural (households relying on "unclean" cooking fuel and found in rural areas); Clean urban (households using "clean" cooking fuels and found in urban areas); and clean rural (households using "clean" cooking fuels and found in rural areas).

\section{Compositional And Contextual Variables}

Variables which relate to an individual's socio-demographic characteristics (biosocial and socio-cultural factors) together constitute compositional factors (Collins et al., 2017; Pol \& Thomas, 2001). Biosocial factors refer to underlying biological and physical attributes present in an individual at birth and are not amenable to change. Socio-cultural factors on the other hand refers to customs, beliefs, lifestyles and values (Armah et al., 2018).

Biosocial variables considered in this study included: sex of child (male, female); current age of child in years with categories $0,1,2,3$, and 4; age of mother (15-19, 20-24, 25-29, 30-34, 35-39,40-44, 45-49); sex of household head (male, female); age of household head ("young adult" for those below 35years, middle-age adult for $35-55$ years, and "old-age adult" for those above 55 years).

The study considered socio-cultural factors including: educational attainment of mother (no education, primary, secondary, tertiary); birth order number (1, 2, 3, 4, 5 and above); household size (small: 1-5, medium: 6-10, large: above 10). Also, the DHS collects data on wealth index of all interviewed households and place them into five wealth quintiles (poorer, poor, middle, rich, richer). Observations of wealth index under poorer and poor were combined and recoded as "poor". Similarly, observations under "rich" and "richer" were combined and recoded as "rich". Finally, household source of drinking water and type toilet facility which were both categorized into "improved" and "unimproved".

According to studies (Collins et al., 2017; Ross \& Mirowsky, 2008), contextual factors refers to those factors related to respondent's neighbourhood attributes or opportunities and services that are space-bound (Armah et al., 2018; Collins et al., 2017; Ross \& Mirowsky, 2008). Contextual factors considered in this study include country and geographic region (Western Africa, Eastern Africa, Southern Africa, and Central Africa).

\section{Data Analysis}


The Stata 14 MP software was used for the analysis of data. To understand the distribution of childhood anaemia and influence of predictive factors on anaemia, descriptive analysis was performed. We then determined the associations between anaemia status of children under five and the relevant predictors using inferential statistics. These relationships were further examined using multivariate techniques while controlling for theoretically relevant compositional and contextual factors. Statistical significance of 0.05 and $95 \%$ confidence interval $(\mathrm{Cl})$ were used in analysis and results presented as contingency tables.

\section{Univariate Analysis}

Pearson chi-square test of independence and Cramer's V statistic were applied in the univariate analysis of predictors of child under five anaemia. The strength of associations between anaemia status and the predictors was tested using Cramer's V statistics.

\section{Multivariate Regression}

The outcome variable (anaemia status of children under age 5 ) had $57 \%$ of responses in the non-affirmative and $43 \%$ were affirmative. The relationship between anaemia status and the interactive effect of household cooking fuel and urbanicity was analysed using negative log-log regression model. A negative log-log regression model is apt when the responses to a dichotomous response variable is asymmetric in the [0, 1] interval for which the non-affirmative is more than $55 \%$ as in the case of the response variable in this study (Aitkin et al., 2005; Armah et al., 2019; Fahrmeir \& Tutz, 2013). The likelihood of a child been anaemic was estimated and reported as exponential coefficients - odds ratios (OR). An OR of 1 means that the predictor does not affect the odds of a child been anaemic; $O R>1$ means that the predictor is associated with higher odds of been anaemic; and OR $<1$ means that the predictor is associated with lower odds of been anaemic. Clustering of observations in units of households was controlled by imposing on the models a "cluster" variable, thus, the identification numbers of the respondents at the cluster level. This adjusted the SE leading to statistically robust estimation of parameters.

At the multivariate level, four (4) models were run: the joint effect of household cooking fuel type and urbanicity (Model 1); birth weight and biosocial factors (Model 2), sociocultural (Model 3), and the contextual (Model 4). Literature and parsimony informed the chosen groups of references for the predictor variables in the models. Respondents from urban settings who rely on unclean cooking fuel types "Unclean urban" was chosen for the key predictor. The selected reference group for sex of child and sex of household head was "male". Studies show that males in households are often less worried about children under five years as well as water and sanitation issues (Armah et al., 2018; Mulenga et al., 2017). The selected reference group for current age of child was "0". Young adults and no education were respective selected as reference groups for age of household head and educational attainment of mother. Unimproved was selected as the reference group for source of drinking water and type of toilet facility. The young adult group was selected as the reference group because this is a demographic group in transition and may be unable to provide better services for the family while those with no education has direct effect on ability to afford and capacity to spearhead decision-making of households with respect to better services and conditions. Small household size was selected as the reference group for household size.

\section{Ethical Considerations}

The DHS Program recognizes and adheres to established international and local ethical standards and protocols in its surveys. The ICF International's Institutional Review Board (IRB) through The DHS Program's reviewed and approved all survey procedures and instruments used before implementation. The board aside providing technical assistance to the program ensures that the survey complies with the United States Department of Health and Human Services regulations for the protection of human subjects CFR 46 as well as the laws of the individual countries.

\section{Results \\ Descriptive analysis}

The study included 95,056 children under the age of 5 years from 29 SSA countries. The percentage of children who suffered anaemia was $57 \%$ while those who were not anaemic accounted for $43 \%$. A majority (57\%) of the children included in the survey were in rural households that used unclean cooking fuels. The results indicate that only $13 \%$ of children under the age of 5 years are from household that rely on clean cooking fuel whiles $87 \%$ lived in households using unclean cooking fuels. Further, prevalence of anaemia was highest (59\%) among children in urban households that use unclean cooking fuels, and rural households that use cleaning cooking fuels. Even though a majority of children were in households with improved source of drinking water (75\%); and improved toilet facility (54\%), most of these children, $58 \%$ and $60 \%$ respectively suffered anaemia. Child anaemia is high (60\%) among children in rich households, which constitute a slightly higher percentage (41\%) of households by wealth status. Even though a relatively high percentage (35\%) of children included in the study were in rural households of poor wealth status, a majority (59\%) of children from rich households in rural areas were anaemic. On educational attainment of mothers, only a few children (4\%) belonged to mothers who had tertiary education, most (65\%) of whom were anaemic. Notwithstanding the relatively few children from Namibia (1\%) and Rwanda (4\%) included in the survey, each recorded $82 \%$ child anaemia. Despite accounting for only $4 \%$ of the children studied, Benin recorded the least (31\%) prevalence of child anaemia. Categorizing the countries into their geographical location, we found that, of the $17 \%$ and $18 \%$ of children from Southern Africa and Central Africa, $74 \%$ of children each region suffered anaemia.

The probability $(P)$ value of all variables except sex of child were significant. The Pearson Chi-squared analysis therefore rejects the null hypotheses that anaemia level is independent of source of drinking water and toilet facility as well as compositional and contextual factors. These results therefore signify that household source of drinking water and type of toilet facility affect anaemia level of children under five years old. Again, the P-values show that the 
figures obtained for anaemia level were not by chance and if the analyses were repeatedly run, same results would be obtained. Cramer's v statistics however shows weak to moderate associations between the key predictor, compositional and contextual factors. The contingency Table 3 shows the detailed results. 
Table 3

Percentage distribution of Anaemia level by predictor variables.

\begin{tabular}{|c|c|c|c|c|}
\hline \multirow[t]{2}{*}{ Variable $\chi 2(d f)$ ( $p$-value; Cramer's V) } & \multirow[t]{2}{*}{ Weighted $\mathrm{n}$} & \multirow[t]{2}{*}{ Weighted \% } & \multicolumn{2}{|c|}{ Anaemia status } \\
\hline & & & Yes (\%) & No $(\%)$ \\
\hline \multicolumn{5}{|c|}{ Household cooking fuel $\chi 2=0.2206(1) ;(p=0.639 ;$ Cramér's V = 0.0015) } \\
\hline Unclean & 83,077 & 87 & 57 & 43 \\
\hline Clean & 11,978 & 13 & 57 & 43 \\
\hline \multicolumn{5}{|c|}{ Household cooking fuel Urbanicity $\chi 2=38.3022(3) ;(p<0.001$; Cramér's V = 0.0200) } \\
\hline Unclean Urban & 29,148 & 31 & 59 & 41 \\
\hline Unclean Rural & 53,930 & 57 & 56 & 44 \\
\hline Clean Urban & 6,055 & 6 & 56 & 44 \\
\hline Clean Rural & 5,923 & 6 & 59 & 42 \\
\hline \multicolumn{5}{|c|}{ Drinking water source $\chi 2=80.0251(1) ;(p<0.001 ;$ Cramér's V = -0.0290) } \\
\hline Unimproved & 23,298 & 25 & 54 & 46 \\
\hline Improved & 71,758 & 75 & 58 & 42 \\
\hline \multicolumn{5}{|c|}{ Type of toilet facility $\chi 2=357.2000(1) ;(p<0.001 ;$ Cramér's V = -0.0612) } \\
\hline Unimproved & 43,618 & 46 & 54 & 46 \\
\hline Improved & 51,438 & 54 & 60 & 40 \\
\hline \multicolumn{5}{|c|}{ Wealth status $\chi 2=281.9885(2) ;(p<0.001 ;$ Cramér's V = 0.0544) } \\
\hline Poor & 37,185 & 39 & 55 & 45 \\
\hline Middle & 18,619 & 20 & 54 & 46 \\
\hline Rich & 39,251 & 41 & 60 & 40 \\
\hline \multicolumn{5}{|c|}{ Sex of child $\chi 2=3.5696(1) ;(p=0.059 ;$ Cramér's V =-0.0061) } \\
\hline Male & 47,997 & 50 & 57 & 43 \\
\hline Female & 47,058 & 50 & 57 & 43 \\
\hline \multicolumn{5}{|c|}{ Birth weight $\chi 2=17.9842(1) ;(p<0.001 ;$ Cramér's V = -0.0140) } \\
\hline Under weight & 13,571 & 15 & 56 & 44 \\
\hline Normal & 77,283 & 85 & 58 & 42 \\
\hline \multicolumn{5}{|c|}{ Current age of child $\chi 2=58.1591(4) ;(p<0.001 ;$ Cramér's V = 0.0252) } \\
\hline 0 & 17,418 & 19 & 56 & 44 \\
\hline 1 & 20,043 & 22 & 55 & 45 \\
\hline 2 & 18,454 & 20 & 57 & 43 \\
\hline 3 & 18,205 & 20 & 58 & 42 \\
\hline 4 & 16,878 & 19 & 59 & 41 \\
\hline \multicolumn{5}{|c|}{ Age of mother(years) $\chi 2=111.3956(6) ;(p<0.001 ;$ Cramér's V = 0.0342) } \\
\hline $15-19$ & 1,415 & 7 & 56 & 44 \\
\hline $20-24$ & 4,784 & 22 & 59 & 41 \\
\hline $25-29$ & 5,830 & 27 & 57 & 43 \\
\hline $30-34$ & 4,745 & 22 & 55 & 45 \\
\hline $35-39$ & 3,246 & 15 & 54 & 46 \\
\hline $40-44$ & 1,328 & 6 & 57 & 43 \\
\hline $45-49$ & 342 & 2 & 56 & 44 \\
\hline \multicolumn{5}{|c|}{ Urbanicity Wealth $\chi 2=395.6355(5) ;(p<0.001$; Cramér's V = 0.0644) } \\
\hline Urban Poor & 4,187 & 4 & 50 & 50 \\
\hline
\end{tabular}




\begin{tabular}{|c|c|c|c|c|}
\hline \multirow[t]{2}{*}{ Variable $x 2(d f)$ ( $p$-value; Cramer's V) } & \multirow[t]{2}{*}{ Weighted $n$} & \multirow[t]{2}{*}{ Weighted \% } & \multicolumn{2}{|c|}{ Anaemia status } \\
\hline & & & Yes (\%) & No (\%) \\
\hline Urban Middle & 4,735 & 5 & 50 & 50 \\
\hline Urban Rich & 26,281 & 28 & 61 & 39 \\
\hline Rural Poor & 32,998 & 35 & 55 & 45 \\
\hline Rural Middle & 13,884 & 15 & 56 & 44 \\
\hline Rural Rich & 12,970 & 14 & 59 & 41 \\
\hline \multicolumn{5}{|c|}{ Birth order number $\chi 2=128.4928(4) ;(p<0.001 ;$ Cramér's V = 0.0367) } \\
\hline 1 & 23,293 & 25 & 59 & 41 \\
\hline 2 & 19,367 & 20 & 58 & 42 \\
\hline 3 & 15,437 & 16 & 58 & 42 \\
\hline 4 & 11,803 & 12 & 56 & 44 \\
\hline 5 and above & 25,155 & 26 & 54 & 46 \\
\hline \multicolumn{5}{|c|}{ Age of household head $\chi 2=116.8819(2) ;(p<0.001 ;$ Cramér's V = 0.0350) } \\
\hline Young adult & 37,260 & 39 & 59 & 41 \\
\hline Middle-aged adult & 44,680 & 47 & 56 & 44 \\
\hline Older-adults & 13,115 & 14 & 54 & 46 \\
\hline \multicolumn{5}{|c|}{ Mother's highest level of education $\chi 2=1.1 e+03(3) ;(p<0.001 ;$ Cramér's V = 0.1056) } \\
\hline No formal education & 28,082 & 30 & 49 & 51 \\
\hline Primary & 35,506 & 37 & 59 & 41 \\
\hline Secondary & 27,968 & 29 & 61 & 39 \\
\hline Tertiary & 3,499 & 4 & 65 & 35 \\
\hline \multicolumn{5}{|c|}{ Household size X2 = 306.2649(2); $(p<0.001 ;$ Cramér's V = 0.0567) } \\
\hline Small & 41,898 & 44 & 59 & 41 \\
\hline Medium & 41,620 & 44 & 57 & 43 \\
\hline Large & 11,538 & 12 & 50 & 50 \\
\hline \multicolumn{5}{|c|}{ Country $\chi 2=7.3 e+03(28) ;(p<0.001 ;$ Cramér's V = 0.2773) } \\
\hline Angola & 5,038 & 5 & 37 & 63 \\
\hline Benin & 3,533 & 4 & 31 & 69 \\
\hline Burkina Faso & 7,030 & 7 & 52 & 48 \\
\hline Burundi & 6,722 & 7 & 58 & 42 \\
\hline Cameroon & 3,345 & 4 & 61 & 39 \\
\hline Congo & 1,653 & 2 & 48 & 52 \\
\hline Cote D'Ivoire & 1,906 & 2 & 45 & 55 \\
\hline DR Congo & 3,737 & 4 & 58 & 42 \\
\hline Ethiopia & 1,919 & 2 & 75 & 25 \\
\hline Gabon & 2,858 & 3 & 43 & 57 \\
\hline Gambia & 1,707 & 2 & 39 & 61 \\
\hline Ghana & 1,412 & 1 & 58 & 42 \\
\hline Guinea & 1,675 & 2 & 56 & 44 \\
\hline Lesotho & 1,202 & 1 & 72 & 28 \\
\hline Malawi & 4,773 & 5 & 69 & 31 \\
\hline Mali & 2,136 & 2 & 44 & 56 \\
\hline Mozambique & 4,102 & 4 & 39 & 61 \\
\hline
\end{tabular}

Page 8/16 


\begin{tabular}{|c|c|c|c|c|}
\hline \multirow[t]{2}{*}{ Variable $\chi 2(d f)$ ( $p$-value; Cramer's V) } & \multirow[t]{2}{*}{ Weighted $\mathrm{n}$} & \multirow[t]{2}{*}{ Weighted \% } & \multicolumn{2}{|c|}{ Anaemia status } \\
\hline & & & Yes (\%) & No $(\%)$ \\
\hline Namibia & 1,831 & 2 & 82 & 18 \\
\hline Niger & 1,428 & 2 & 59 & 41 \\
\hline Nigeria & 2,758 & 3 & 46 & 54 \\
\hline Rwanda & 3,547 & 4 & 82 & 18 \\
\hline Sierra Leone & 2,425 & 3 & 55 & 45 \\
\hline Senegal & 2,484 & 3 & 49 & 51 \\
\hline Tanzania & 7,430 & 8 & 54 & 46 \\
\hline Togo & 1,853 & 2 & 56 & 44 \\
\hline Uganda & 3,415 & 4 & 69 & 31 \\
\hline Zambia & 7,174 & 8 & 73 & 27 \\
\hline Zimbabwe & 4,891 & 5 & 75 & 25 \\
\hline South Africa & 1,069 & 1 & 72 & 28 \\
\hline \multicolumn{5}{|c|}{ Geographic region $\chi 2=3.9 e+03(3) ;(p<0.001 ;$ Cramér's V = 0.2019) } \\
\hline Western Africa & 30,348 & 32 & 48 & 52 \\
\hline Eastern Africa & 31,909 & 34 & 61 & 39 \\
\hline Southern Africa & 16,167 & 17 & 74 & 26 \\
\hline Central Africa & 16,632 & 18 & 74 & 26 \\
\hline
\end{tabular}

\section{Multivariate Analysis}

Table 4 shows the results from the negative log-log regression analysis on the relationship between type of household cooking fuel and anaemia among children under five in SSA. In Model 4, the final model that controlled for all the variables including country, it was found that children from rural households that depend on unclean cooking fuels were more likely to be anaemic [AOR $=1.042 ; 95 \% \mathrm{Cl}=1.010-1.074]$ as compared to children from urban households using unclean cooking fuel. With birthweight, it was found from our study that children with normal weight had lower odds [AOR =0.946; $\mathrm{Cl}=0.916-0.976]$ of being anaemic compared to underweight children. The odds of suffering from anaemia decreased with age of the child. It was found that children aged 4 had the lowest odds $[A O R=0.900 ; \mathrm{Cl}=0.868-0.934]$ of suffering from anaemia compared with those less than 1 year $(0)$. With maternal age, compared with those age 15-19, all the age categories showed statistically significant association with anaemia. However, children whose mother are aged 45-49 [AOR $=0.866 ; \mathrm{Cl}$ $=0.778-0.963]$ and those aged $30-34[\mathrm{AOR}=0.868 ; \mathrm{Cl}=0.815-0.925]$ had the lowest odds of being anaemic. We also found that children in female headed households [AOR = 1.047; $\mathrm{Cl}=1.019-1.076]$; middle aged adults [AOR $=1.046 ; \mathrm{Cl}=1.016-1.076]$, old age adults $[\mathrm{AOR}=1.078 ; \mathrm{Cl}=1.049-1.118]$ were more likely to be anaemic compared with those in male headed households; and households headed by young adults. With regards to educational attainment of child's mother, children whose mother's highest educational attainment is the tertiary level had the lowest odds $[\mathrm{AOR}=0.865 ; \mathrm{Cl}=0.809-0.925]$ of suffering from anaemia compared with those whose mothers had no formal education.

The result show that children in large households $[A O R=1.066 ; \mathrm{Cl}=1.021-1.113]$; those in households with improved source of drinking water $[\mathrm{AOR}=1.035$; $\mathrm{Cl}=1.006-1.065]$ had higher odds of being suffering from anaemia compared to those in small household and those whose source of drinking is unimproved respectively. Children in rich households $[\mathrm{AOR}=0.935 ; \mathrm{Cl}=0.904-0.968]$; those in household with improved type of toilet facility $[\mathrm{AOR}=0.955 ; \mathrm{Cl}=0.929-$ 0.981] had lower odds of being anaemic compared with those in poor households, and households with unimproved toilet facility respectively. With country, apart from Benin, all the children in the other countries had lower odds of being anaemic with those in Namibia having the lowest odds $[\mathrm{AOR}=0.267$; $\mathrm{Cl}=$ 0.243-0.293] compared to children in Angola (see Table 4). 
Table 4

Negative log-log regression model showing the relationship between Anaemia status and predictor variables

\begin{tabular}{|c|c|c|c|c|c|c|c|c|c|c|c|c|c|c|c|c|}
\hline \multirow[t]{3}{*}{ Variables } & \multicolumn{5}{|c|}{ Key Predictor } & \multicolumn{5}{|c|}{ Key Predictor + Biosocial factors } & \multicolumn{6}{|c|}{ Socio-cultural factors } \\
\hline & \multicolumn{5}{|c|}{ Model 1} & \multicolumn{5}{|c|}{ Model 2} & \multicolumn{5}{|c|}{ Model 3} & $\mathbf{N}$ \\
\hline & OR & $\begin{array}{l}\text { Robust } \\
\text { SE }\end{array}$ & $\begin{array}{l}P \\
\text { value }\end{array}$ & \multicolumn{2}{|c|}{ Conf. Interval } & AOR & $\begin{array}{l}\text { Robust } \\
\text { SE }\end{array}$ & $\begin{array}{l}P \\
\text { value }\end{array}$ & \multicolumn{2}{|c|}{ Conf. Interval } & AOR & $\begin{array}{l}\text { Robust } \\
\text { SE }\end{array}$ & $\begin{array}{l}P \\
\text { value }\end{array}$ & \multicolumn{2}{|c|}{ Conf. Interval } & A \\
\hline \multicolumn{17}{|c|}{ Household cooking fuel Urbanicity (ref: Unclean Urban) } \\
\hline $\begin{array}{l}\text { Unclean } \\
\text { Rural }\end{array}$ & 1.068 & 0.012 & 0.000 & 1.044 & 1.093 & 1.045 & 0.013 & 0.000 & 1.020 & 1.070 & 0.905 & 0.013 & 0.000 & 0.879 & 0.931 & 1. \\
\hline $\begin{array}{l}\text { Clean } \\
\text { Urban }\end{array}$ & 1.062 & 0.027 & 0.017 & 1.011 & 1.115 & 1.074 & 0.028 & 0.006 & 1.020 & 1.129 & 1.071 & 0.028 & 0.008 & 1.018 & 1.127 & 1. \\
\hline $\begin{array}{l}\text { Clean } \\
\text { Rural }\end{array}$ & 1.001 & 0.024 & 0.972 & 0.955 & 1.049 & 0.997 & 0.025 & 0.903 & 0.949 & 1.047 & 0.880 & 0.023 & 0.000 & 0.835 & 0.926 & 0 . \\
\hline \multicolumn{17}{|c|}{ Birth weight (ref: Underweight) } \\
\hline Normal & & & & & & 0.945 & 0.015 & 0.000 & 0.916 & 0.975 & 0.953 & 0.015 & 0.002 & 0.923 & 0.983 & 0 . \\
\hline \multicolumn{17}{|c|}{ Sex (ref: Male) } \\
\hline Female & & & & & & 0.987 & 0.011 & 0.244 & 0.966 & 1.009 & 0.986 & 0.011 & 0.206 & 0.965 & 1.008 & 0 . \\
\hline \multicolumn{17}{|c|}{ Current age of child (ref: 0 ) } \\
\hline 1 & & & & & & 1.004 & 0.017 & 0.819 & 0.971 & 1.039 & 0.996 & 0.017 & 0.796 & 0.962 & 1.030 & 0 . \\
\hline 2 & & & & & & 0.973 & 0.017 & 0.114 & 0.939 & 1.007 & 0.969 & 0.017 & 0.074 & 0.936 & 1.003 & 0 . \\
\hline 3 & & & & & & 0.958 & 0.017 & 0.015 & 0.925 & 0.992 & 0.958 & 0.017 & 0.017 & 0.924 & 0.992 & 0 \\
\hline 4 & & & & & & 0.930 & 0.017 & 0.000 & 0.897 & 0.963 & 0.937 & 0.017 & 0.000 & 0.903 & 0.971 & 0 \\
\hline \multicolumn{17}{|c|}{ Age of mother (ref: 15-19) } \\
\hline $20-24$ & & & & & & 0.907 & 0.025 & 0.000 & 0.860 & 0.956 & 0.890 & 0.025 & 0.000 & 0.843 & 0.940 & 0 \\
\hline $25-29$ & & & & & & 0.899 & 0.024 & 0.000 & 0.853 & 0.947 & 0.839 & 0.025 & 0.000 & 0.792 & 0.889 & 0 \\
\hline $30-34$ & & & & & & 0.863 & 0.024 & 0.000 & 0.818 & 0.910 & 0.778 & 0.025 & 0.000 & 0.731 & 0.828 & 0 \\
\hline $35-39$ & & & & & & 0.898 & 0.026 & 0.000 & 0.848 & 0.951 & 0.797 & 0.028 & 0.000 & 0.744 & 0.854 & 0 \\
\hline $40-44$ & & & & & & 0.898 & 0.030 & 0.001 & 0.841 & 0.958 & 0.772 & 0.031 & 0.000 & 0.714 & 0.834 & 0 \\
\hline $45-49$ & & & & & & 0.921 & 0.044 & 0.086 & 0.838 & 1.012 & 0.756 & 0.040 & 0.000 & 0.681 & 0.840 & 0 \\
\hline \multicolumn{17}{|c|}{ Sex of household head (ref: Male) } \\
\hline Female & & & & & & 0.975 & 0.013 & 0.061 & 0.950 & 1.001 & 1.005 & 0.014 & 0.685 & 0.979 & 1.032 & 1. \\
\hline \multicolumn{17}{|c|}{ Age of household head (ref: Young adults) } \\
\hline $\begin{array}{l}\text { Middle- } \\
\text { aged } \\
\text { adults }\end{array}$ & & & & & & 1.106 & 0.015 & 0.000 & 1.077 & 1.136 & 1.066 & 0.015 & 0.000 & 1.036 & 1.096 & 1. \\
\hline Old-aged & & & & & & 1.194 & 0.022 & 0.000 & 1.152 & 1.237 & 1.109 & 0.022 & 0.000 & 1.067 & 1.153 & 1. \\
\hline
\end{tabular}

\section{Educational attainment of mother (ref: No education)}

Primary

Secondary

Tertiary

Birth order number(ref: 1)

2

3

4

5 and

above

\begin{tabular}{llllll}
0.734 & 0.011 & $\mathbf{0 . 0 0 0}$ & 0.714 & 0.755 & 0. \\
0.727 & 0.012 & $\mathbf{0 . 0 0 0}$ & 0.705 & 0.751 & 0. \\
\hline 0.718 & 0.022 & $\mathbf{0 . 0 0 0}$ & 0.676 & 0.762 & 0.
\end{tabular}

$\begin{array}{llllll}1.053 & 0.018 & 0.003 & 1.018 & 1.089 & 0 .\end{array}$

$\begin{array}{llllll}1.063 & 0.021 & 0.002 & 1.022 & 1.106 & 1 .\end{array}$

$\begin{array}{llllll}1.107 & 0.026 & 0.000 & 1.057 & 1.160 & 1 .\end{array}$

$\begin{array}{llllll}1.120 & 0.028 & 0.000 & 1.068 & 1.176 & 1 .\end{array}$

Household size (ref: Small) 


\begin{tabular}{|c|c|c|c|c|c|c|c|c|c|c|c|c|c|c|}
\hline \multirow[t]{3}{*}{ Variables } & \multicolumn{4}{|c|}{ Key Predictor } & \multicolumn{4}{|c|}{ Key Predictor + Biosocial factors } & \multicolumn{5}{|c|}{ Socio-cultural factors } & \multirow{2}{*}{$\frac{\mathrm{C}}{\mathrm{N}}$} \\
\hline & \multicolumn{4}{|c|}{ Model 1} & \multicolumn{4}{|c|}{ Model 2} & \multicolumn{5}{|c|}{ Model 3} & \\
\hline & OR & $\begin{array}{l}\text { Robust } \\
\text { SE }\end{array}$ & $\begin{array}{l}P \\
\text { value }\end{array}$ & Conf. Interval & AOR & $\begin{array}{l}\text { Robust } \\
\text { SE }\end{array}$ & $\begin{array}{l}\mathrm{P} \\
\text { value }\end{array}$ & Conf. Interval & AOR & $\begin{array}{l}\text { Robust } \\
\text { SE }\end{array}$ & $\begin{array}{l}\mathrm{P} \\
\text { value }\end{array}$ & Conf. & terval & A \\
\hline Medium & & & & & & & & & 1.034 & 0.014 & 0.015 & 1.007 & 1.062 & 1. \\
\hline Large & & & & & & & & & 1.188 & 0.025 & 0.000 & 1.140 & 1.239 & 1. \\
\hline \multicolumn{15}{|c|}{ Wealth status (ref: Poor) } \\
\hline Middle & & & & & & & & & 1.052 & 0.017 & 0.002 & 1.019 & 1.086 & 1. \\
\hline Rich & & & & & & & & & 0.925 & 0.015 & 0.000 & 0.896 & 0.956 & 0 . \\
\hline \multicolumn{15}{|c|}{ Source of drinking water (ref: Unimproved) } \\
\hline Improved & & & & & & & & & 0.977 & 0.014 & 0.107 & 0.951 & 1.005 & 1. \\
\hline \multicolumn{15}{|c|}{ Type of toilet facility (ref: Unimproved) } \\
\hline Improved & & & & & & & & & 0.926 & 0.012 & 0.000 & 0.903 & 0.950 & 0 . \\
\hline \multicolumn{15}{|c|}{ Country (ref: Angola) } \\
\hline Benin & & & & & & & & & & & & & & 1. \\
\hline $\begin{array}{l}\text { Burkina } \\
\text { Faso }\end{array}$ & & & & & & & & & & & & & & 0 . \\
\hline Burundi & & & & & & & & & & & & & & 0 . \\
\hline Cameroon & & & & & & & & & & & & & & 0. \\
\hline Congo & & & & & & & & & & & & & & 0 . \\
\hline $\begin{array}{l}\text { Cote } \\
\text { D'lvoire }\end{array}$ & & & & & & & & & & & & & & 0 . \\
\hline DR Congo & & & & & & & & & & & & & & 0 . \\
\hline Ethiopia & & & & & & & & & & & & & & 0 . \\
\hline Gabon & & & & & & & & & & & & & & 0 . \\
\hline Gambia & & & & & & & & & & & & & & 0. \\
\hline Ghana & & & & & & & & & & & & & & 0. \\
\hline Guinea & & & & & & & & & & & & & & 0 . \\
\hline Lesotho & & & & & & & & & & & & & & 0 . \\
\hline Malawi & & & & & & & & & & & & & & 0 . \\
\hline Mali & & & & & & & & & & & & & & 0 . \\
\hline Namibia & & & & & & & & & & & & & & 0. \\
\hline Niger & & & & & & & & & & & & & & 0 . \\
\hline Nigeria & & & & & & & & & & & & & & 0 . \\
\hline Rwanda & & & & & & & & & & & & & & 0 . \\
\hline $\begin{array}{l}\text { Sierra } \\
\text { Leone }\end{array}$ & & & & & & & & & & & & & & 0 . \\
\hline Senegal & & & & & & & & & & & & & & 0. \\
\hline Tanzania & & & & & & & & & & & & & & 0. \\
\hline Togo & & & & & & & & & & & & & & 0. \\
\hline Uganda & & & & & & & & & & & & & & 0. \\
\hline Zambia & & & & & & & & & & & & & & 0. \\
\hline Zimbabwe & & & & & & & & & & & & & & 0. \\
\hline $\begin{array}{l}\text { South } \\
\text { Africa }\end{array}$ & & & & & & & & & & & & & & 0. \\
\hline
\end{tabular}




\section{Discussion}

In this current study, our principal aim was to investigate the association between household biomass fuel use, and the joint effect of household biomass fuel use for cooking and urbanicity on anaemia among children under the age of 5 in SSA. The study showed that children from rural households that depend on unclean cooking fuels were more likely to be anemic compared with children from urban households using unclean cooking fuel. This is in line with previous studies in various parts of the world such as Timor-Lest (Pinto, 2016) and India (Page, Patel, \& Hibberd, 2015; Baranwal, Baranwal, \& Roy, 2014). Although this study was a cross-sectional study and could not claim causality, some studies(Page, Patel, \& Hibberd, 2015) have explained that exposure to unclean cooking fuels may lead to systemic inflammation which is regarded as a popular cause of anaemia, mediated by inflammatory cytokines such as tumor necrosis factor alpha (TNF-a), interleukin-1 (IL-1), interleukin-6 (IL-6), and interferon- $\gamma$ (IFN- - ) (Weiss \& Goodnough, 2005). The pathways by which these causes anaemia include dysregulation of iron homeostasis, impaired erythropoietin response to reduced hemoglobin levels, and impaired marrow response to erythropoietin (Weiss \& Goodnough, 2005; Page, Patel, \& Hibberd, 2015). Apart from the key independent variable, we controlled for other key factors associated with anaemia among children under five which are worth discussing in light of previous evidence.

We found that the birthweight of the child had statistically significant association with anaemia. Specifically, children with normal weight had lower odds of being anemic compared with underweight children. This is in consonance with previous studies in Ethiopia (Gebreegziabiher, Etana \& Niggusi, 2014) and Brazil (Santos et al., 2011). Some previous studies espoused that there is a direct link between food consumption and anaemia. Due to this, in household where there is no food security, it can affect the nutritional status of children, which could contribute to anaemia (Ali et al., 2013; Gebreweld, Ali, Ali \& Fisha, 2019). Relatedly, we found that children in large households had higher odds of suffering from anaemia compared to those in small household. This finding confirms a previous study in Ethiopia (Asresie, Fekadu \& Dagnew, 2020). Insufficient consumption of appropriate quantity of nutrients due to the high numbers in the households could possibly account for this observation as explained by Asresie, Fekadu and Dagnew, (2020).

The study also established that the socio-economic status (education and wealth) of women had statistically significant association with child anaemia. Specifically, it was found that children whose mothers are in the rich wealth status as well as those with tertiary level of education have lower odds of being anaemic. This corroborates several previous studies in SSA and other countries such as Ethiopia (Kawo, Asfaw, \& Yohannes, 2018; Woldie, Kebede, \& Tariku, 2015; Gebreegziabiher, Etana, \& Niggusie, 2014), Brazil (Muniz, et al 2007), Switzerland (Prieto-Patron et al., 2018), Burma (Zhao et al., 2012), and India (Pasricha et al., 2010). There are basically three pathways to the explanation of this finding. First, on the supply side, children from households with high-socio economic status are able to buy nutritious foods for their children unlike the poor ones who might not be able to afford three square meals a day. In other words, the poor might lack the resources to purchase nutritious foods for their children. Second, evidence also suggest that mothers in poor households are also anaemic and the probability of their children also being anaemic is high. Thirdly, in terms of education, mothers who are highly educated are able to translate the health education they receive during child welfare clinics into practice. In addition, those who are highly educated are able to recognise danger signs related to childhood illnesses that warrant emergency care (Agbozo et al 2018; Asresie, Fekadu \& Dagnew, 2020).

Another major finding in our study was that the odds of suffering from anaemia decreased with age of the child. This finding is supported by other studies conducted in Ethiopia (Guled et al., 2017; Gebreweld et al., 2019; Gebreegziabiher, Etana, \& Niggusie, 2014; Khan, Awan \& Misu, 2016), Ghana (Parbey et al 2017), and Uganda (Kuziga, Adoke \& Wanyenze, 2017). The possible reason for this association is that in most cases as the children grow, they are able to eat varied foods which might be sufficient in iron and as a result could prevent the occurrence of anaemia (Asresie, Fekadu \& Dagnew, 2020). We also observed statistically significant association between maternal age and child's anaemia. Specifically, children whose mothers are aged 45-49 and those aged 30-34 had the lowest odds of being anemic. This is consistent with previous studies in Ethiopia (Asresie, Fekadu \& Dagnew, 2020). It is possible that as mothers advance in age, they gain experiences with childcare and also, they are more likely to be exposed to education on appropriate practices on childhood nutrition compared with those who are adolescents. In line with a previous study (Engidaye et al., 2019), we also found that children in female headed households, middle aged adults, old age adults were more likely to be anemic compared with those in male headed households; and households headed by young adults. Surprisingly, our study showed that children in households with improved source of drinking water had higher odds of being anaemic. This is contrary to other empirical studies in Bangladesh (Khan, Awan, \& Misu, 2016), India (Baranwal, Baranwal, \& Roy, 2014), Benin and Mali (Ngnie-Teta, Receveur \& Kuate-Defo, 2007). Longitudinal case control studies coupled with qualitative evidence are needed to unravel this counter intuitive finding.

\section{Strengths And Limitation}

The major strength of this study is the use of recent nationally representative surveys, with relatively large sample sizes. This makes the findings generalisable to all under five children in the countries we included in our study. In addition, we employed rigorous statistical modelling to assess the association between the type of cooking fuel and anaemia while controlling for theoretical and practical confounders. The study however, is limited by the cross-sectional nature of the design employed for the data collection. Due to this, it is impossible to detect temporality of sequence. Also, geographic region and Urbanicity Wealth were associated with child anaemia $(p<0.05)$ but could not be included in the model due to multicollinearity.

\section{Conclusion}

Our study found that there is an association between the joint effect of household biomass fuel use for cooking and urbanicity and anaemia among children under the age of 5 in SSA. Apart from this we also found that birthweight of the child, age of the child, maternal age, sex of household head, age of household head, maternal education, wealth status, size of household, type of source of drinking water and country of residence are associated with childhood anaemia. The following recommendations are therefore made for policy and practice. Firstly, it is critical to promote clean fuel usage among households and women in rural areas. This could be done by governments in various countries by enhancing access and subsidising the cost of natural and or, liquified petroleum gas [LPG] and cylinders. Second, it is also imperative to advocate for improvement in female education which could lead to improvement in socio-economic status 
of the women. Thirdly, maternal education by community health nurses on the risk factors of anaemia is also strongly suggested. Stakeholders that seek to improve maternal and child health should also take these associated factors into consideration.

\section{Declarations}

\section{Acknowledgment}

We thank the Demographic and Health Surveys (DHS) Program for swiftly providing access to data upon request.

\section{Author affiliations}

${ }^{1}$ Africa Centre of Excellence in Coastal Resilience, University of Cape Coast, Cape Coast, Ghana

${ }^{2}$ Department of Fisheries and Aquatic Sciences, School of Biological Sciences, College of Agriculture and Natural Sciences, University of Cape Coast, Ghana

${ }^{3}$ Department of Population and Health, University of Cape Coast, Cape Coast, Ghana

${ }^{4}$ College of Public Health, Medical and Veterinary Sciences, James Cook University, Townsville, Queensland, Australia

${ }^{5}$ Department of Environmental Science, School of Biological Sciences, College of Agriculture and Natural Sciences, University of Cape Coast, Ghana

${ }^{6}$ The Australian Centre for Public and Population Health Research (ACPPHR), Faculty of Health, University of Technology Sydney, Australia

\section{Author's contributions}

Conceptualization: I.A; Methodology and Analysis: I.A, A.A.; Writing and edits: AS, BOl; Review: All authors. Content of manuscript was agreed on by all authors

\section{Corresponding author}

Correspondence to Iddrisu Amadu; Email and ORCID ID:iddrisu.amadu@stu.ucc.edu.gh (0000-0003-4839-1197)

\section{*Contributors}

Email addresses and ORCID IDs:

AS: abdul-aziz.seidu@stu.ucc.edu.gh(0000-0001-9734-9054)

AA: jagaafitiri@gmail.com(0000-0002-3437-1673)

BOA: brightahinkorah@gmail.com(0000-0001-7415-895X)

\section{Funding}

Authors received no funding for this study.

\section{Availability of data and materials}

The study used data from the Demographic and Health Surveys Program which is provided upon request.

\section{Ethics and declarations}

We used publicly available, secondary data. Authors of this study had no direct contact with the survey subjects.

\section{Consent for publication}

All the authors approved the manuscript and submission for publication

\section{Competing interests}

The authors declare that they have no competing interests.

\section{References}

1. Abdi Guled R, Mamat NM, Balachew T, Bakar MA, Azdie W, Assefa N. Predictors and prevalence of anaemia, among children aged 6 to 59 months in shebelle zone, Somali region, eastern Ethiopia: a cross sectional study. International Journal of Development Research. 2017;7(1):11189-96.

2. Agbozo F, Colecraft E, Jahn A, Guetterman T. Understanding why child welfare clinic attendance and growth of children in the nutrition surveillance programme is below target: lessons learnt from a mixed methods study in Ghana. BMC nursing. 2018 Dec 1;17(1):25.

3. Aitkin MA, Aitkin M, Francis B, Hinde J. Statistical modelling in GLIM 4. OUP Oxford; 2005. 
4. Alelign T, Degarege A, Erko B. Prevalence and factors associated with undernutrition and anaemia among school children in Durbete Town, northwest Ethiopia. Archives of Public Health. 2015 Dec 1;73(1):34.

5. Ali D, Saha KK, Nguyen PH, Diressie MT, Ruel MT, Menon P, Rawat R. Household food insecurity is associated with higher child undernutrition in Bangladesh, Ethiopia, and Vietnam, but the effect is not mediated by child dietary diversity. The Journal of nutrition. 2013 Dec 1;143(12):2015-21.

6. Armah FA, Ekumah B, Yawson DO, Odoi JO, Afitiri AR, Nyieku FE. Access to improved water and sanitation in sub-Saharan Africa in a quarter century. Heliyon. 2018 Nov 1;4(11):e00931.

7. Armah FA, Odoi JO, Luginaah I. Indoor air pollution and health in Ghana: Self-reported exposure to unprocessed solid fuel smoke. EcoHealth. 2015 Jun $1 ; 12(2): 227-43$.

8. Armah FA, Quansah R, Yawson DO, Abdul Kadir L. Assessment of Self-Reported Adverse Health Outcomes of Electronic Waste Workers Exposed to Xenobiotics in Ghana. Environmental Justice. 2019 Apr 1;12(2):69-84.

9. Asresie MB, Fekadu GA, Dagnew GW. Determinants of Anaemia among Children Aged 6-59 Months in Ethiopia: Further Analysis of the 2016 Ethiopian Demographic Health Survey. Advances in Public Health. 2020 Mar 31;2020.

10. Baranwal A, Baranwal A, Roy N. Association of household environment and prevalence of anaemia among children under-5 in India. Frontiers in public health. 2014 Oct;20:2:196.

11. Begum BA, Paul SK, Hossain MD, Biswas SK, Hopke PK. Indoor air pollution from particulate matter emissions in different households in rural areas of Bangladesh. Build Environ. 2009 May;44(5)(1):898-903.

12. Bruce N, Dherani M, Liu R, Hosgood HD, Sapkota A, Smith KR, Straif K, Lan Q, Pope D. Does household use of biomass fuel cause lung cancer? A systematic review and evaluation of the evidence for the GBD 2010 study. Thorax. 2015 May 1;70(5):433 - 41.

13. Cardoso MA, Scopel KK, Muniz PT, Villamor E, Ferreira MU. Underlying factors associated with anaemia in Amazonian children: a population-based, crosssectional study. PloS one. 2012 May;4(5):e36341. 7(.

14. Chakraborty D, Mondal NK, Datta JK. Indoor pollution from solid biomass fuel and rural health damage: A micro-environmental study in rural area of Burdwan, West Bengal. International Journal of sustainable built environment. 2014 Dec 1;3(2):262 - 71.

15. Collins J, Ward BM, Snow P, Kippen S, Judd F. Compositional, contextual, and collective community factors in mental health and well-being in Australian rural communities. Qual Health Res. 2017 Apr;27(5):677-87.

16. World Health Organization

Desai MA, Mehta S, Smith KR. World Health Organization. Indoor smoke from solid fuels: assessing the environmental burden of disease at national and local levels. World Health Organization; 2004.

17. Engidaye G, Melku M, Yalew A, Getaneh Z, Asrie F, Enawgaw B. Under nutrition, maternal anaemia and household food insecurity are risk factors of anaemia among preschool aged children in Menz Gera Midir district, Eastern Amhara, Ethiopia: a community-based cross- sectional study. BMC public health. 2019 Dec;19(1):968.

18. Fahrmeir L, Tutz G. Multivariate statistical modelling based on generalized linear models. Springer Science \& Business Media; 2013 Mar 14.

19. Fosu MO, Frimpong FO, Arthur MO. Factors associated with haemoglobin prevalence among Ghanaian children aged 6-59 months. J Biology Agric Healthc. 2014;4(2):132-40.

20. Gayawan E, Arogundade ED, Adebayo SB. Possible determinants and spatial patterns of anaemia among young children in Nigeria: a Bayesian semiparametric modelling. International health. 2014 Mar;6(1)(1):35-45.

21. Gebreegziabiher G, Etana B, Niggusie D. Determinants of anaemia among children aged 6-59 months living in Kilte Awulaelo Woreda, Northern Ethiopia. Anaemia. 2014 Jan 1;2014.

22. Gebreweld A, Ali N, Ali R, Fisha T. Prevalence of anaemia and its associated factors among children under five years of age attending at Guguftu health center, South Wollo, Northeast Ethiopia. PloS one. 2019 Jul;5(7):e0218961. 14(.

23. Gener JPAD, Glader BE, Paraskevas F, Foerster J, Lukens JN, et al. Wintrobe's clinical hematology. 13th ed. Philadelphia: Lippincott Williams \& Wilkins; 2013. p. 2312.

24. Hawkins P, Blackett I, Heymans C. Poor-inclusive urban sanitation: An overview. 2013.

25. Kawo KN, Asfaw ZG, Yohannes N. Multilevel analysis of determinants of anaemia prevalence among children aged 6-59 Months in Ethiopia: classical and bayesian approaches. Anaemia. 2018 Jun 3;2018.

26. Khan JR, Awan N, Misu F. Determinants of anaemia among 6-59 months aged children in Bangladesh: evidence from nationally representative data. BMC pediatrics. 2016 Dec 1;16(1):3.

27. Kurmi OP, Lam KB, Ayres JG. Indoor air pollution and the lung in low-and medium-income countries. 2012.

28. Kurmi OP, Semple S, Devereux GS, Gaihre S, Lam KB, Sadhra S, Steiner MF, Simkhada P, Smith WC, Ayres JG. The effect of exposure to biomass smoke on respiratory symptoms in adult rural and urban Nepalese populations. Environ Health. 2014 Dec;13(1)(1):92.

29. Kuziga F, Adoke Y, Wanyenze RK. Prevalence and factors associated with anaemia among children aged 6 to 59 months in Namutumba district, Uganda: a cross-sectional study. BMC pediatrics. 2017 Dec 1;17(1):25.

30. Machisa M, Wichmann J, Nyasulu PS. Biomass fuel use for household cooking in Swaziland: is there an association with anaemia and stunting in children aged 6-36 months?. Transactions of the Royal Society of Tropical Medicine and Hygiene. 2013 Sep 1;107(9):535 - 44.

31. Magalhaes RJ, Clements AC. Mapping the risk of anaemia in preschool-age children: the contribution of malnutrition, malaria, and helminth infections in West Africa. PLoS Med. 2011 Jun;7(6):e1000438. 8(. 
32. Malkanthi RL, Silva KD, Jayasinghe-Mudalige UK. Risk factors associated with high prevalence of anaemia among children under 5 years of age in paddyfarming households in Sri Lanka. FoodNutr Bull. 2010 Dec;31(4):475-82.

33. McHugh ML. The chi-square test of independence. Biochemia medica: Biochemia medica. 2013 Jun 15;23(2):143-9.

34. Mishra V, Retherford RD. Does biofuel smoke contribute to anaemia and stunting in early childhood?. International Journal of Epidemiology. 2007 Feb 1;36(1):117 - 29.

35. Mulenga JN, Bwalya BB, Kaliba-Chishimba K. Determinants and inequalities in access to improved water sources and sanitation among the Zambian households. International Journal of Development Sustainability. 2017;6(8):746-62.

36. Muniz PT, Castro TG, Araújo TS, Nunes NB, Silva-Nunes MD, Hoffmann EH, Ferreira MU, Cardoso MA. Child health and nutrition in the Western Brazilian Amazon: population- based surveys in two counties in Acre State. Cadernos de Saúde Pública. 2007 Jun;23(6):1283-93.

37. Nambiema A, Robert A, Yaya I. Prevalence and risk factors of anaemia in children aged from 6 to 59 months in Togo: analysis from Togo demographic and health survey data, 2013-2014. BMC public health. 2019 Dec 1;19(1):215.

38. Naz S, Page A, Agho KE. Household air pollution from use of cooking fuel and under-five mortality: The role of breastfeeding status and kitchen location in Pakistan. PLoS One. 2017.

39. Mar. 9;12(3):e0173256.

40. Ngnie-Teta I, Receveur O, Kuate-Defo B. Risk factors for moderate to severe anaemia among children in Benin and Mali: insights from a multilevel analysis. FoodNutr Bull. 2007 Mar;28(1):76-89.

41. Ntenda PA, Nkoka O, Bass P, Senghore T. Maternal anaemia is a potential risk factor for anaemia in children aged 6-59 months in Southern Africa: a multilevel analysis. BMC public health. 2018 Dec 1;18(1):650.

42. Oluwole O, Arinola GO, Huo D, Olopade CO. Household biomass fuel use, asthma symptoms severity, and asthma underdiagnosis in rural schoolchildren in Nigeria: a cross-sectional observational study. BMC pulmonary medicine. 2017 Dec 1;17(1):3.

43. Page CM, Patel A, Hibberd PL. Does smoke from biomass fuel contribute to anaemia in pregnant women in Nagpur, India? A cross-sectional study. PloS one. 2015 May 29;10(5):e0127890.

44. Parbey PA, Kyei-Duodu G, Takramah W, Tarkang E, Agboli E, Takase M, Kweku M. Prevalence of anaemia and associated risk factors among children under five years in hohoe municipality, Ghana. Journal of Scientific Research Reports. 2017 Aug;1:1-2.

45. Pasricha SR, Black J, Muthayya S, Shet A, Bhat V, Nagaraj S, Prashanth NS, Sudarshan H, Biggs BA, Shet AS. Determinants of anaemia among young children in rural India. Pediatrics. 2010 Jul 1;126(1):e140-9.

46. Pinto VS. An analysis of association between using solid fuel and anaemia among reproductive age women, 15-49 years old in Timor-Leste.

47. Pol LG, Thomas RK. The demography of health and health care. Springer Science \& Business Media; 2001.

48. Prieto-Patron A, Van der Horst K, Hutton ZV, Detzel P. Association between anaemia in children 6 to 23 months old and child, mother, household and feeding indicators. Nutrients. 2018 Sep;10(9):1269.

49. Ross CE, Mirowsky J. Neighborhood socioeconomic status and health: context or composition? City Community. 2008 Jun;7(2):163-79.

50. Santos RF, Gonzalez ES, Albuquerque EC, Arruda IK, Diniz AD, Figueroa. Pereira JN. AP.

51. Prevalence of anaemia. in under five-year-old children in a children's hospital in Recife, Brazil.

52. Revista brasileira de hematologia e hemoterapia. 2011;33(2):100-4.

53. Simbauranga RH, Kamugisha E, Hokororo A, Kidenya BR, Makani J. Prevalence and factors associated with severe anaemia amongst under-five children hospitalized at Bugando Medical Centre, Mwanza, Tanzania. BMC hematology. 2015 Dec;15(1):13.

54. Soliman AT, De Sanctis V, Kalra S. Anaemia and growth. Indian J Endocrinol Metab. 2014;18(1):1-5.

55. Sood A, Assad NA, Barnes PJ, Churg A, Gordon SB, Harrod KS, Irshad H, Kurmi OP, Martin WJ, Meek P, Mortimer K. ERS/ATS workshop report on respiratory health effects of household air pollution. European Respiratory Journal. 2018 Jan 1;51(1).

56. Sreeramareddy CT, Shidhaye RR, Sathiakumar N. Association between biomass fuel use and maternal report of child size at birth-an analysis of 2005-06 India Demographic Health Survey data. BMC public health. 2011 Dec 1;11(1):403.

57. Tolentino K, Friedman JF. An update on anaemia in less developed countries. Am J Trop Med Hyg. 2007 Jul;77(1)(1):44-51.

58. Van Gemert F, Chavannes N, Kirenga B, Jones R, Williams S, Tsiligianni I, Vonk J, Kocks J, De Jong C, Van Der Molen T. Socio-economic factors, gender and smoking as determinants of COPD in a low-income country of sub-Saharan Africa: FRESH AIR Uganda. NPJ primary care respiratory medicine. 2016 Sep 1;26(1):1-6.

59. Weiss G, Goodnough LT. Anaemia of chronic disease. New England Journal of Medicine. 2005 Mar 10;352(10):1011-23.

60. White N. Anaemia and malaria. Malar J. 2018;17:371.

61. WHO. Air quality guidelines for particulate matter, ozone, nitrogen dioxide and sulfur dioxide. Global update 2005. Summary of risk assessment. Geneva: World Health Organization; 2006, WHO/SDE/ PHE/OEH/06.02.

62. WHO. Air quality guidelines for particulate matter, ozone, nitrogen dioxide and sulfur dioxide. Global update 2005. Summary of risk assessment. Geneva: World Health Organization; 2006, WHO/SDE/ PHE/OEH/06.02.

63. WHO. Global nutrition targets 2025: anaemia policy brief. Geneva: World Health Organization; 2014. http://apps.who.int/iris/bitstream/10665/148556/1/WHO_NMH_NH_14.4_eng.pdf?ua=1.

64. WHO. Haemoglobin concentrations for the diagnosis of anaemia and assessment of severity. Vitamin and Mineral Nutrition Information System. Geneva, World Health Organization 2011.http:// www.who.int/vmnis/indicators/haemoglobin.pdf.

Page $15 / 16$ 
65. Wirth JP, Rohner F, Woodruff BA, Chiwile F, Yankson H, Koroma AS, Russel F, Sesay F, Dominguez E, Petry N, Shahab-Ferdows S Anaemia, micronutrient deficiencies, and malaria in children and women in Sierra Leone prior to the Ebola outbreak-findings of a cross-sectional study. PLoS One. 2016 May 10;11(5):e0155031.

66. Woldie H, Kebede Y, Tariku A. Factors associated with anaemia among children aged 6-23 months attending growth monitoring at Tsitsika Health Center, Wag-Himra Zone, Northeast Ethiopia. Journal of nutrition and metabolism. 2015 May 27;2015.

67. Woolley KE, Bagambe T, Singh A, Avis WR, Kabera T, Weldetinsae A, Mariga ST, Kirenga B, Pope FD, Thomas GN, Bartington SE. Investigating the Association between Wood and Charcoal Domestic Cooking, Respiratory Symptoms and Acute Respiratory Infections among Children Aged Under 5 Years in Uganda: A Cross-Sectional Analysis of the 2016 Demographic and Health Survey. International Journal of Environmental Research Public Health. 2020 Jan;17(11):3974.

68. World Health Organization (WHO). Household Air Pollution and Health. Available online: https://www.who.int/news-room/fact-sheets/detail/householdair-pollution-and-health.

69. World Health Organization. Progress on drinking water, sanitation and hygiene: 2017 update and SDG baselines.

70. Xin QQ, Chen BW, Yin DL, Xiao F, Li RL, Yin T, Yang HM, Zheng XG, Wang LH. Prevalence of anaemia and its risk factors among children under 36 months old in China. Journal of tropical pediatrics. $2017 \mathrm{Feb}$ 1;63(1):36-42.

71. Yaya S, Uthman OA, Ekholuenetale M, Bishwajit G, Adjiwanou V. Effects of birth spacing on adverse childhood health outcomes: evidence from 34 countries in sub-Saharan Africa. The Journal of Maternal-Fetal \& Neonatal Medicine. 2019 Feb 8:1-8.

72. Zhao A, Zhang Y, Peng Y, Li J, Yang T, Liu Z, Lv Y, Wang P. Prevalence of anaemia and its risk factors among children 6-36 months old in Burma. The American journal of tropical medicine and hygiene. 2012 Aug 1;87(2):306 - 11.

\section{Figures}

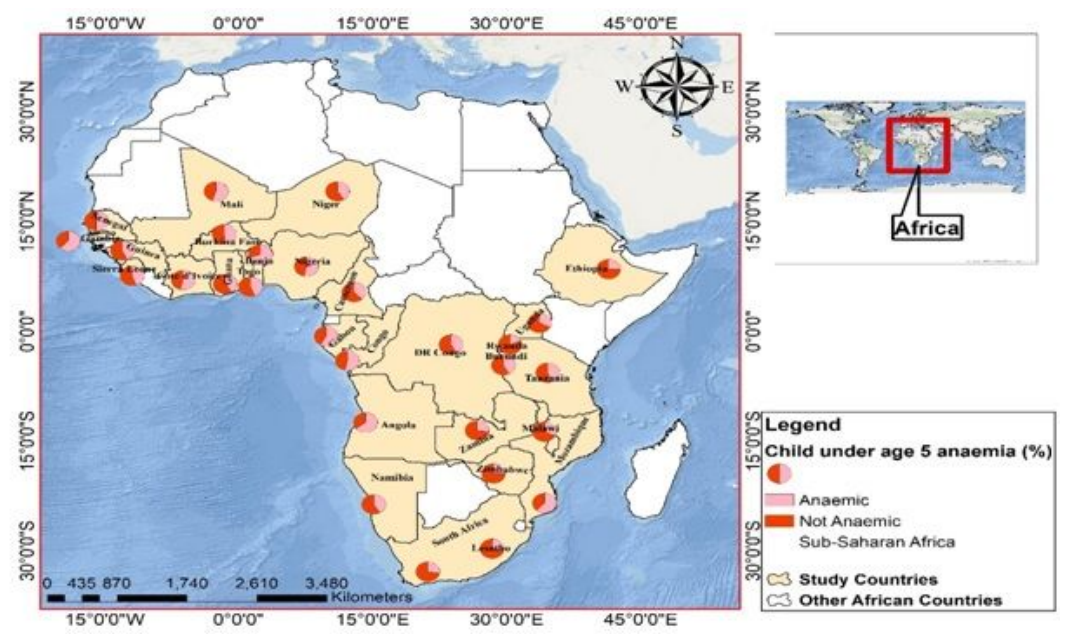

Figure 1

Map of study countries with spatial representation of child under age 5 anaemia 